\title{
講座 LECTURE
}

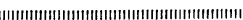

6. 高 温 腐 食 ${ }^{*}$

原田良 夫**

\section{High Temperature Corrosion}

by

\section{Yoshio HARADA}

(Takasago Technical Institute, Mitsubishi Heavy Industries, Ltd., Takasago)

\section{$6 \cdot 1$ ま え がき}

金属を空気中で加熱すると，空気と接触している表 面に薄い酸化膜が生成し，これがある程度厚く成長す るといわゆるスケールとなり，その量が多くなって金 属が消耗すると酸化腐食とよばれるようになる。

高温腐食の基礎となる金属酸化の理論は幾つか提案 されている. 例兄ば, 酸化膜が比較的厚く, その成長 速度が各種の化学種（イオンまたは電子）の膜内移動 速度に律せられ，膜厚に逆比例するとする Wagner の理諭や, 酸化膜が薄く, 表面に形成される電気二重 層の強い電場の影響が無視できない場合についての Mott の理論などが有名で，また多くの優れた解説書 も出版されている.

ここでは実プラントを取扱う立場に立って, 高温腐 食の代表事例として，酸化，硫化，浸炭，水素侵害 (食)捛よび窒化腐食の機構とその特徵について述べる.

\section{$6 \cdot 2$ 酸 化 腐 食}

\section{$6 \cdot 2 \cdot 1$ 酸化反応の概要}

金属 $(\mathrm{M})$ と酸素 $\left(\mathrm{O}_{2}\right)$ が反応して酸化物を生成す る場合の反応式は，一般に次のように表される.

$$
\mathrm{M}+\mathrm{O}_{2} \rightleftarrows \mathrm{MO}_{2}
$$

この反応は条件によって右方向に移行したり(酸化)， 左方向（還元）へ進む可逆反応であり, 条件が一定に 保持されていると次第に平衡状態に近づく．この反応 系では温度が与えられると平衡酸素圧は一定值をとる こととなるので，これを解離圧とよび，環境中の酸素 圧が解離压より高ければ酸化反応が進行し, 低ければ 還元反応が起る.

(1)式の平衡定数を $K_{a}$ とすれば，

$$
K_{a}=a(\mathrm{MO}) / a(\mathrm{M}) a\left(\mathrm{O}_{2}\right)
$$

aはそれぞれの成分の活量を示す. (2)式は次のように 書き直すことができる.

$$
K_{a}=1 / f\left(\mathrm{O}_{2}\right) \cdot a^{\prime}(\mathrm{MO}) / a^{\prime}(\mathrm{M})
$$

* 原稿受理 昭和52年11月29日

** 三菱重工業(株)高砂研究所 高砂市荒井町新㙃
ここではM特よび MO はいずれも 1 (固体の活量 は 1 である) であり， $\mathrm{O}_{2}$ を理想気体であるとすれば， $K_{a}$ は単に,

$$
K_{p}=1 / \mathrm{po}_{2}
$$

となる.ここに $\mathrm{po}_{2}$ は $\mathrm{O}_{2}$ 分圧. すなわちこの種の 平衡定数では固体の活量を 1 とし, 反応物の項を含め なくてもよいのが通則である.

したがって，自由エネルギの変化 $\Delta F$ は次のように なる。

$$
-\Delta F=R T \ln K=R T \ln \mathrm{p}_{2}
$$

ここでRは気体定数， $T$ は絶対温度である.

この結果から明らかなように, 酸化反応の進行に伴 う自由エネルギの変化が大きい葟ど $\mathrm{po}_{2}$ は小さくなり その酸化物は安定であることとなる。

また，解離圧 $p$ と酸化熱 $W$ とは次の上うな関係にあ り，酸化熱の大きい注ぞ解離圧は小さく，金属と酸素 との親和力が大きく，その酸化物は安定であることと なる。

$$
\log p=-W / 4.578 T+1.75 \log T+2.8
$$

ここで, $W$ 酸素 1 分子当りの酸化熱である.

金属の酸化，還元反応に伴う $\Delta F$ は，温度に対して $\Delta F=a+b T$ のように表されるので，酸化物に対して は図 $6 \cdot 1$ の上うな関係にある。 この図は金属と酸素 が反応する場合の平衡状態を見い出すのに便利であり， 引いては腐食反応の可能性や腐食環境を推定するのに 役立つ場合が多い.

たと党ば、ニッケル酸化物 $\mathrm{NiO}$ の $1000{ }^{\circ} \mathrm{C}$ に抒け る解離圧は図から次の上らに求められる。すなおち $\Delta F$ の直線から,

$$
\begin{gathered}
\Delta F_{1273^{\circ} \mathrm{K}}=R T \ln \mathrm{p}_{\mathrm{O}_{2}}-57000 \mathrm{cal} / \mathrm{mol} \\
\mathrm{pO}_{2} \fallingdotseq 1 \times 10^{-10} \mathrm{~atm}
\end{gathered}
$$

となるが，これは図の左側縦軸上の $\mathrm{O}$ 点と $\mathrm{NiO}$ 線上 の $1000{ }^{\circ}$ Cに拈ける $\Delta F$ とを結んで, 右側縦軸の $\mathrm{po}_{2}$ 線まで延長した交点の值を読むことによって容易に求 められる. $\mathrm{H}_{2} / \mathrm{H}_{2} \mathrm{O}$ 比および $\mathrm{CO} / \mathrm{CO}_{2}$ 比の線は, そ 


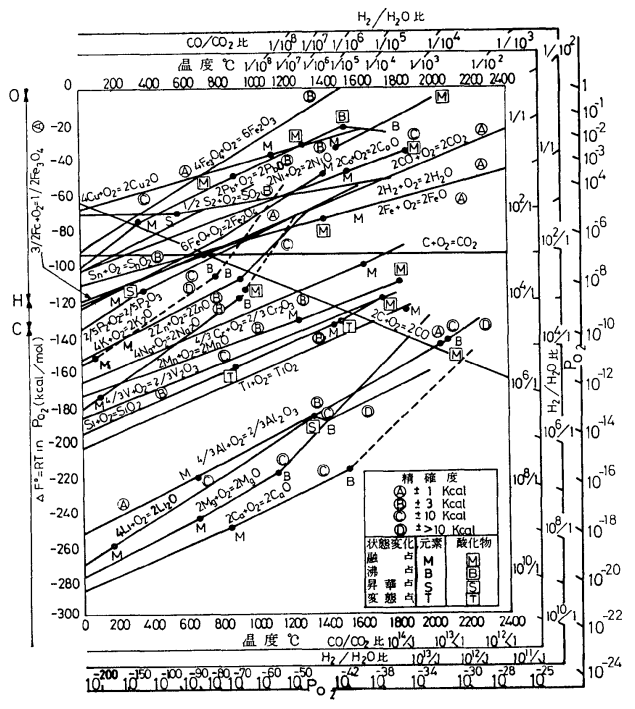

図 $6 \cdot 1$ 酸化物の自由エネルギ温度図

れぞれ水素および CO で還元する場合の条件を求める もので, 前者は左縦軸の $\mathrm{H}$ 点, 後者は $\mathrm{C}$ 点と $\mathrm{NiO}$ 線 上の $1000^{\circ} \mathrm{C}$ 扮ける $\Delta F$ 点を結んで，それぞれの延 長線の交点を結べばその值が読める.

\section{$6 \cdot 2 \cdot 2$ 酸化腐食の機構および速度}

金属を空気中で加熱すると，その表面に酸化膜を生 成して次第に消耗して行く. しかし酸化膜が形成した 後の金属と $\mathrm{O}_{2}$ との反応は, 酸化膜を介して行われる ため，一般に反応速度は遅くなるとともに，酸化膜内 部の各位置における酸素解離圧 $\left(\mathrm{pO}_{2}\right)$ は空気/酸化物 界面 $\left(\mathrm{po}_{2}{ }^{\prime \prime}\right)$ を最大として，酸化物/金属界面側 $\left(\mathrm{po}_{2}{ }^{\prime}\right)$ へ移るに従って小さくなり，それぞれの $\mathrm{po}_{2}$ に対応す る酸化物が安定相となって膜内に存在することとなる. 鉄を空気中で加熱すると四 6 ・2 に示すように，空気 側から $\mathrm{Fe}_{2} \mathrm{O}_{3}, \mathrm{Fe}_{3} \mathrm{O}_{4}, \mathrm{FeO}$ 層の順に構成されるが, これらは前述の理由から説明することができる。この ような多層構造を有する酸化膜では, 緻密で最も厚く 発達する酸化物層中での拡散速度が，その金属の酸化 速度を律速することとなり，一般に $x^{2}=K_{p} t$ なる放物 線則で表すことができる。ここで $x$ は単位面積当りの 重量增加 $\left(\mathrm{mg} / \mathrm{cm}^{2}\right), t$ は時間 $(\mathrm{h}), K_{p}$ は定数であ る.

金属イオンの拡散のみによって酸化膜が成長する場

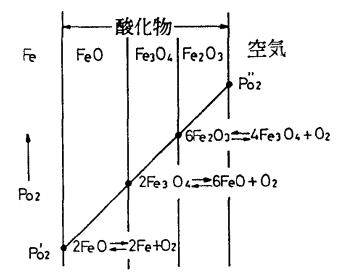

図 $6 \cdot 2$ 酸化膜の構造例
合には, この $K_{p}$ は酸化膜中における金属イオンの自 己拡散係数 $\left(D_{M}\right)$ に上り次のように表される.

$$
K_{p}=C \int_{\mathrm{p}_{\mathrm{O}_{2}}{ }^{\prime}}^{\mathrm{pO}{ }^{\prime \prime}} D_{M} \ln \mathrm{p}_{\mathrm{O}_{2}}
$$

ここでCは金属イオン濃度である.この式から明ら かなように, 酸化膜の成長速度は $D_{M}$ の大きいほど大 となる. 表 6 ・I 亿実用されている耐熱金属材料を空 気中で加熱した場合に生成される酸化物について，金 属イオンの自己拡散保数を示した.

金属の酸化速度は, 金属の種類, 温度, 時間和よび 酸素分圧などの条件によって変化するが, 表 6・II 示すような速度式が知られている. 同一金属であって も, 低温では対数則に従い，高温になるに従って放物 線則, 直線則に変化することがあるので, 一つの式で 表現することが困難な場合が多い，たと兄ば一定温度 で加熱すると，その表面に生成される酸化膜が緻密で 一様に金属表面を覆うと, 以後の反応はこの酸化物を 通しての抬散速度に律速されて放物線則となるが, 酸 化膜の成長過程では応力が発生して膜にき裂ができた り,はく離したりするとこれらの欠陥部から酸素が侵 入し，再び金属と直接反応することとなるので酸化速 度は再び大きくなる。このよらなことから金属の耐酸 化性が良好であるためには, 次のような条件を具備す る必要がある。

（1）表面に形成される酸化膜が緻密で均一であり, さらに膜内に抢ける金属イオンや酸素イオンの拡散係

表 6 ・I 酸化物中の金属イオンの自己拡散係数 $\left(1000^{\circ} \mathrm{C}\right)$

\begin{tabular}{l|l}
\hline 酸化物 & \multicolumn{1}{|c}{ 自己拡散係数 $\left(\mathrm{cm}^{2} / \mathrm{sec}\right)$} \\
\hline $\mathrm{FeO}$ & $9 \times 10^{-3}$ \\
$\mathrm{Fe}_{3} \mathrm{O}_{3}$ & $2 \times 10^{-9}$ \\
$\alpha-\mathrm{Fe}_{2} \mathrm{O}_{3}$ & $2 \times 10^{-13}$ \\
$\mathrm{CoO}$ & $3 \times 10^{-9}$ \\
$\mathrm{NiO}$ & $1 \times 10^{-11}$ \\
$\mathrm{Cr}_{2} \mathrm{O}_{3}$ & $3 \times 10^{-14}$ \\
$\alpha-\mathrm{Al}_{2} \mathrm{O}_{3}$ & $3 \times 10^{-17}$ \\
$\mathrm{CoCr}_{2} \mathrm{O}_{4}$ & $\mathrm{Co}: 1.7 \times 10^{-12}, \mathrm{Cr}: 1.9 \times 10^{-12}$ \\
$\mathrm{NiCr}_{2} \mathrm{O}_{4}$ & $\mathrm{Ni}: 1.4 \times 10^{-13}, \mathrm{Cr}: 2.8 \times 10^{-13}$ \\
$\mathrm{NiAl}_{2} \mathrm{O}_{4}$ & $\mathrm{Ni}: 1 \times 10^{-13}$ \\
$\mathrm{SiO}_{2}$ & $\mathrm{O}: 1.3 \times 10^{-18}, \mathrm{Si}$ はれより小さい \\
$\mathrm{MnO}^{\mathrm{MnO}}$ & $1 \times 10^{-10}\left(\mathrm{Po}_{2}=10^{-16} \mathrm{~atm}\right)$ \\
\hline
\end{tabular}

表 $6 \cdot$ II 酸化現象の関係式

\begin{tabular}{|c|c|c|}
\hline $\begin{array}{l}\text { 洼則の } \\
\text { 類 }\end{array}$ & 現 & 備 \\
\hline 直 線 則 & $x=K_{l} t$ & 表面反応律速型 \\
\hline 放物線則 & $x^{2}=K_{p} t$ & 拡散律速型（厚いスケール） \\
\hline 三乗根則 & $x^{3}=K_{c} t$ & 同 上 $(x \sim 1000 \AA)$ \\
\hline 対 数 則 & $x=K^{\prime} \log \left(t_{0}+t\right)+A$ & $\begin{array}{r}\text { 電子のトンネル効果律速型 } \\
(x<100 \AA)\end{array}$ \\
\hline 逆対数則 & $1 / x=A^{\prime}-K^{\prime \prime} \log t$ & 強電場内移動型 $(x<100 \AA)$ \\
\hline
\end{tabular}

注） $x$ はスケール厚, $K_{l}, K_{p}, K_{c}, K^{\prime}$ および $K^{\prime \prime}$ は各法則式の 速度定数 $A, A^{\prime}$ は常数. 
数が小さいこと.

（2）割れや，き裂の発生しない酸化膜であること.

（3）割れやき裂あるいは酸化膜の部分はく離が発生 しても, 直に保護性の酸化膜を再生すること.

このため, 高温で使用される金属材料には(1)〜(3)の

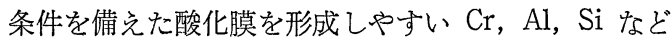
が合金元素として添加されている.

\section{$6 \cdot 2 \cdot 3$ 加速酸化腐食}

金属の酸化が酸化腐食として問題となるのは，環境 温度がその金属特有の耐酸化限界温度以上であるか， 限界温度以下であっても，酸化膜の保護性が損われる 上らな物理, 化学的作用が働く環境に曝された場合で ある。

（1）物理的加速作用 物理的作用の要因としては, 成長しつつある酸化膜中に組織変化や異相の生成など に起因する応力が発生し，酸化膜がこの応力に耐え切 れなくなって，き裂を発生したり，酸化膜／金属界面 に空孔が発生して接合面積が減少するか，あるいは接 合力が弱くて酸化膜が界面からはく離するなどの膜の 破瞂と，生成する酸化物が低融点で高い蒸気圧（たと えば $\mathrm{V}_{2} \mathrm{O}_{5}, \mathrm{MoO}_{3}$ ) であるために消耗が激しいなどの 酸化膜自体の現象が挙げられる。交た酸化膜の破壊現 象を助長する環境因子として，温度が絶えず変化し加 熱, 冷却の繰返しが長期間にわたって行われる場合が ある. 表 $6 ・ \mathbb{I I I}$ に示すように金属とその表面に生成す る酸化膜の熱膨張係数が異るため, 加熱冷却の繰返し 時に大きな応力が発生し，部分的あるいは広、範囲に わたって，き裂，はく離現象が絶え間なく起り，また 温度変化がない場合でも強い振動や衝撃が加党られる よらな環境でも，同じょうな現象によって酸化が甚だ しく促進されることとなる。な挔，以上のような物理 的加速作用は，すべての腐食反応に共通しており，高 温酸化のみの特徵ではない。

（2）化学的加速作用 加速酸化の要因が化学的因子 に起因する場合の代表事例としては，重油燃焼ガス中

表 $6 ・ \mathbb{I I I}$ 金属とその酸化物の熱膨張係数の比較

\begin{tabular}{|c|c|c|c|c|c|}
\hline & \multicolumn{2}{|c|}{ 酸 化 物 } & \multicolumn{2}{|c|}{ 金属 } & \multirow{2}{*}{$\begin{array}{c}\text { 比 } \\
\left(\alpha_{m} / \alpha_{O x}\right)\end{array}$} \\
\hline & $\begin{array}{c}\text { 膨張係数 } \\
\left(\alpha_{O x}\right)\end{array}$ & $\begin{array}{c}\text { 温度範囲 } \\
\left({ }^{\circ} \mathrm{C}\right)\end{array}$ & $\begin{array}{c}\text { 膨張係数 } \\
\left(\alpha_{m}\right)\end{array}$ & $\begin{array}{c}\text { 温度範囲 } \\
\left({ }^{\circ} \mathrm{C}\right)\end{array}$ & \\
\hline $\mathrm{Fe}-\mathrm{FeO}$ & $12.2^{\times 10^{-6}}$ & $100 \sim 1000$ & $15.3^{\times 10^{-6}}$ & $0 \sim 900$ & 1.25 \\
\hline $\mathrm{Fe}-\mathrm{Fe}_{2} \mathrm{O}_{3}$ & 14.9 & $20 \sim 900$ & 15.3 & $0 \sim 900$ & 1.03 \\
\hline $\mathrm{Ni}-\mathrm{NiO}$ & 171 & $20 \sim 1000$ & 176 & $0 \sim 1000$ & 1.03 \\
\hline $\mathrm{Co}-\mathrm{CoO}$ & 15.0 & $20 \sim 900$ & 15.9 & $600 \sim 900$ & 106 \\
\hline $\mathrm{Co}-\mathrm{Co}_{3} \mathrm{O}_{4}$ & 13.6 & $20 \sim 900$ & 15.9 & $600 \sim 900$ & 1.17 \\
\hline $\mathrm{Cr}-\mathrm{Cr}_{2} \mathrm{O}_{3}$ & 7.3 & $100 \sim 1000$ & 95 & $0 \sim 1000$ & 130 \\
\hline $\mathrm{Cu}-\mathrm{Cu}_{2} \mathrm{O}$ & 4.3 & $25 \sim 750$ & 18.6 & $0 \sim 800$ & 4.32 \\
\hline $\mathrm{Cu}-\mathrm{CuO}$ & 9.3 & $20 \sim 600$ & 186 & $0 \sim 800$ & 2.00 \\
\hline
\end{tabular}

に括けるV化合物を含む低融点油㓹による腐食が有名 である，溶融塩／金属系の腐食では，水溶液／金属系 と異り溶質濃度が非常に高く，溶媒がなくなった極限 状態であると考えられるので，腐食反応としては非常 飞複雑なところもあるが，平衡論的には水溶液の場合 と同様熱力学的数字を用いて腐食系の自由エネルギ変 化を知り，その值が負で大きいほぼ腐食反応が進行す ると考它て差支党ない。

$$
M+M^{\prime} X \longrightarrow M^{\prime}+M X
$$

$-\Delta F=R T \ln K=R T \ln \left[a\left(M^{\prime}\right) a(M) X / a(M) a\left(M^{\prime} X\right)\right]$

ここで，Mは金属または金属イオン，Xは八ログン， 硫酸塩などの陰イオン, $a\left(M^{\prime} X\right)$ は $\mathrm{M}^{\prime} X$ 成分の活量 である。

また，溶融塩／金属系にお打る腐食では，ガス／金 属のように反応生成物が金属表面に蓄積することが少 く, 溶融塩中に溶けることが多いので, 酸化膜のような 反応生成物による防食効果は期待できにくい，また環 境中の酸素をよく吸収して金属の酸化を促進させる他, 共存する $\mathrm{SO}_{x}, \mathrm{CO}_{x}$ などの影響により，溶融塩が分 解して腐食性のガスを放出したり，他の化合物へ変化 するなど溶融塩そのものの物性が变化する特徵がある.

重油灰中には多くの低融点 $\mathrm{V}$ 化合物（例光ば $5 \mathrm{NaO}$ - $\left.\mathrm{V}_{2} \mathrm{O}_{4} \cdot 11 \mathrm{~V}_{2} \mathrm{O}_{5}, \mathrm{~m} . \mathrm{p} .535^{\circ} \mathrm{C}\right)$ が含まれて和り, 腐食 作用を営む酸素は，低融点の $\mathrm{V}$ 化合物が凝固してバナ ジウム塩からバナジル・バナジウム塩へ変化するとき に発生し，溶融時には四収する可逆反応によって供給 され腐食が進行する。

$$
\begin{aligned}
& m \mathrm{Na}_{2} \mathrm{O} \cdot n \mathrm{~V}_{2} \mathrm{O}_{5} \underset{\text { 溶融 }}{\stackrel{\text { 凝固 }}{\rightleftarrows}} m \mathrm{Na}_{2} \mathrm{O} \cdot p \mathrm{~V}_{2} \mathrm{O}_{4} \cdot(n-p) \mathrm{V}_{2} \mathrm{O}_{5} \\
& +1 / 2 \mathrm{pO}_{2}^{6)} \\
& \mathrm{Na}_{2} \mathrm{O} \cdot 6 \mathrm{~V}_{2} \mathrm{O}_{5} \underset{\text { 溶融固 }}{\stackrel{\text { 点 }}{\rightleftarrows}} \mathrm{Na}_{2} \mathrm{O} \cdot \mathrm{V}_{2} \mathrm{O}_{4} \cdot 5 \mathrm{~V}_{2} \mathrm{O}_{5}+1 / 2 \mathrm{O}_{2}
\end{aligned}
$$

また， $\mathrm{V}_{2} \mathrm{O}_{5}-\mathrm{Na}_{2} \mathrm{SO}_{4}$ 系の灰によって発生する気体 は温度によって異り，次のように550〜 $900^{\circ} \mathrm{C}$ 籁囲で は酸化力の強い $\mathrm{SO}_{3}$ と $\mathrm{O}_{2}$ が, $1000^{\circ} \mathrm{C}$ では $\mathrm{SO}_{3}$ が発 生するとともに，いずれの場合も腐食性の低融点化合 物を生成する特徵がある。

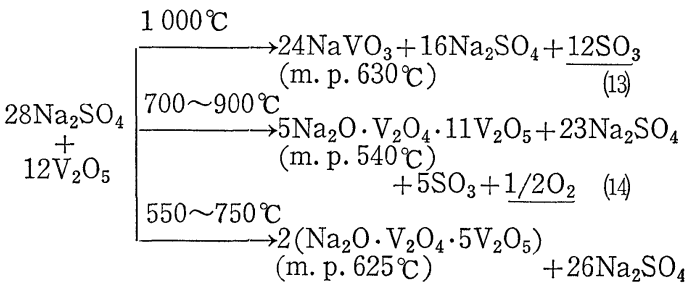

$$
\begin{aligned}
& +2 \mathrm{SO}_{3}+\underline{\mathrm{O}_{2}} \text { (15) }
\end{aligned}
$$

一方，金属側からバナジウム腐食をみると，金属表 
面に接触した溶融状のV化合物によって, 絶觉ずふん 囲気中の酸素が運び込まれるので，この酸素によって 金属が酸化されるとともに, 生成した酸化物がV化合 物の融体によって破壊され, 多孔質となって保護皮膜 としての効果を消失する．また融体の表面張力が低く， フラックスとしての作用も具備しているため, 酸化物 が化学的に溶解除去される傾向が強く, 苛酷な腐食が 発生することとなる.

\section{$6 \cdot 3$ 硫 化 腐 食}

\section{$6 \cdot 3 \cdot 1$ ガス/金属系の腐食}

金属を高温の $\mathrm{SO}_{x}, \mathrm{H}_{2} \mathrm{~S}$ 抢よびアルカリ硫酸塩化 合物などのS 化合物を含を環境に置くと, 硫化物を生 成して消耗するが，反応機構拉よび速度はS 化合物の 種類によってかなり異る.

$\mathrm{SO}_{x} /$ 金属系に和ける腐食では, 次のような反応に よって金属酸化物および硫化物を生成するとともに を遊離する. $\mathrm{p}_{\mathrm{S}_{2}} / \mathrm{p}_{\mathrm{O}_{2}}$ の関係から酸化鉄が環境側に, 硫化物は金属側存在することとなる.

$$
\begin{aligned}
& \mathrm{M}+\mathrm{SO}_{2} \longrightarrow \mathrm{MS}+\mathrm{O}_{2} \\
& 2 \mathrm{M}+\mathrm{SO}_{2} \longrightarrow 2 \mathrm{MO}+\mathrm{S}
\end{aligned}
$$

この系の腐食は一般に緩やかであり, 問題となること は少い。

$\mathrm{H}_{2} \mathrm{~S} /$ 金属系の腐食反応は, $\mathrm{H}_{2} \mathrm{~S}$ 濃度, 水素分圧打 よび温度の影響を強く受ける。水素分圧の腐食に対す る影響は次のように表されている。

$$
R=a P^{0.4} C^{0.4}
$$

ここに $R$ は腐食度, $P$ は全圧, $C$ は水素モル分圧, $a$ は定数である.

このように水素分圧の高い添ど腐食量は增加するが， これは硫化反応によって生成した硫化物が水素によっ て還元される反応が局部的炕行われる結果, 多孔質で 保護性のない腐食層が生成されるためである.

S/金属系の反応によって生成した硫化物層の断面 は図 6 ・3 亿示すと挍りであり, $\mathrm{Fe}-\mathrm{Cr}$ 合金鋼の例で は, 外側から $\mathrm{FeS}, \mathrm{Cr}_{3} \mathrm{~S}_{4},\left(\mathrm{FeS}, \mathrm{Cr}_{x} \mathrm{~S}_{y}\right.$ ) の順に $\mathrm{P}_{\mathrm{S}_{2}}$ 分圧飞見合ら硫化物が腐食層となって構成される.中 間層の $\mathrm{Cr}_{3} \mathrm{~S}_{4}$ は, 外層から供給される $\mathrm{S}$ 合金から の Cr によって生成し, 外層の成長は中間層を拡散し てくる Fe によってのみ成長するので, 中間層におけ

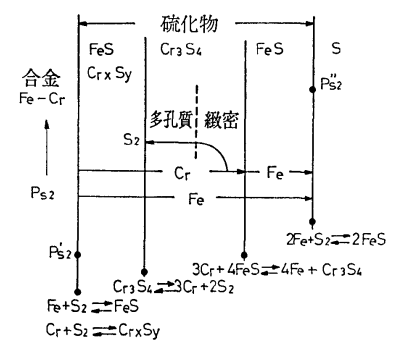

図 6 -3 $\mathrm{Fe}$ - $\mathrm{Cr}$ 合金鋼の $\mathrm{S}$ による腐食層の構造例
るFeの拡散速度は，Cr よりも早い（103倍）ことにな りこのような系に和ける硫化腐食も放物線則に従う こととなる。しかしその速度は，酸化の場合の約 $10^{6}$ 倍大きいといわれ格子久宿が大きく，耐熱性に乏しい 腐食層を形成する特徵がある.

\section{$6 \cdot 3 \cdot 2$ 溶融塩/金属系の腐食}

この系の腐食は, 燃焼ガス中に含まれる $\mathrm{Na}_{2} \mathrm{SO}_{4}$ に よる硫化腐食や，石炭焚きボイラの高温腐食に抢ける アルカリ硫酸塩錯化合物による作用が有名である．腐 食反応は一般に次の上らに示され，腐食生成物は硫化 物と酸化物であるが，V化合物と異り酸素が存在しな い環境でも腐食が進行する特徵がある。

$$
\begin{gathered}
\mathrm{Na}_{2} \mathrm{SO}_{4}+3 \mathrm{R} \longrightarrow \mathrm{Na}_{2} \mathrm{O}+3 \mathrm{RO}+\mathrm{S} \\
\mathrm{M}+\mathrm{S} \longrightarrow \mathrm{MS} \\
\mathrm{Na}_{2} \mathrm{SO}_{4}+3 \mathrm{MS} \longrightarrow \mathrm{Na}_{2} \mathrm{O}+3 \mathrm{MO}+4 \mathrm{~S}
\end{gathered}
$$

ここに R は不特定の還元剂, Mは金属元素である. $\mathrm{Ni}$ 扤よび Cr を例にとってこの反応を示すと，

$$
\begin{gathered}
\mathrm{Na}_{2} \mathrm{SO}_{4}+9 / 2 \mathrm{Ni} \longrightarrow \mathrm{Na}_{2} \mathrm{O}+3 \mathrm{NiO}+1 / 2 \mathrm{Ni}_{3} \mathrm{~S}_{2} \text { (22) } \\
\mathrm{Na}_{2} \mathrm{O}+1 / 2 \mathrm{Cr}_{2} \mathrm{O}_{3}+3 / 4 \mathrm{O}_{2} \longrightarrow \mathrm{Na}_{2} \mathrm{CrO}_{4} \quad \text { (23) }
\end{gathered}
$$

結局

$$
\begin{aligned}
\mathrm{Na}_{2} \mathrm{SO}_{4}+9 / 2 \mathrm{Ni}+1 / 2 \mathrm{Cr}_{2} \mathrm{O}_{3}+3 / 4 \mathrm{O}_{2} \\
\longrightarrow \mathrm{Na}_{2} \mathrm{CrO}_{4}+3 \mathrm{NiO}+1 / 2 \mathrm{Ni}_{3} \mathrm{~S}_{2}
\end{aligned}
$$

また

$$
2 \mathrm{Cr}+\mathrm{Ni}_{3} \mathrm{~S}_{2} \longrightarrow 2 \mathrm{CrS}+3 \mathrm{Ni}
$$

の反応を認められて拈り, 低融点 $\left(645^{\circ} \mathrm{C}\right)$ の $\mathrm{Ni}-\mathrm{Ni}_{3} \mathrm{~S}_{2}$ 共晶体の生成と, 耐酸化拉よび耐食性の要因である $\mathrm{Cr}$ の硫化物への変化が顕著な腐食を誘発したり，消耗を 促進させる原因となって拈り, 硫化腐食の大きな特徴 といえる.

\section{$6 \cdot 4$ 浸 炭 腐 食}

ナフサや LPG などの石油系原料を熱分解する石油 化学プラントでは, 浸炭腐食が問題となる. 浸炭現象 が発生するためには，(1)環境中または金属表面におけ るCの析出，(2)浸炭を妨げる表面酸化物の還元，(3)金 属中への C の拡散と炭化物の形成などの作用が必要で 西る. Cの析出は環境を構成する C 化合物の炭素析出 反応の $K_{P}$ を, 酸化物の還元性は, 同じように酸化物 と還元性ガスとの酸化-還元反応の $K_{P}$ を，また炭化 物の生成反応は, 金属元素と C との炭化物生成反応の $K_{P}$ を爷れぞれ求め, 使用温度環境組成の $K_{P}{ }^{\prime}$ が各反 応の $K_{P}$ とどのような関係沈るかを求め, $K_{P}^{\prime} / K_{P}$ が1より大きい場合はとれぞれの反応が進み，小さい 場合は進まないことで, 㐨抒よとの反応の進行を推定 することが可能である.たと兊ば図 $6 \cdot 4$ 亿浸炭一脱炭 反応特よび炭化物生成反応における熱力学的平衡例を 示したが, 使用温度に朝ける環境ガスの $K_{P}{ }^{\prime}$ が各反応 の平衡定数 $K_{P}$ より下にくる場合は反応は右へ，上方 にくる場合は左方向へ進むこととなる。 


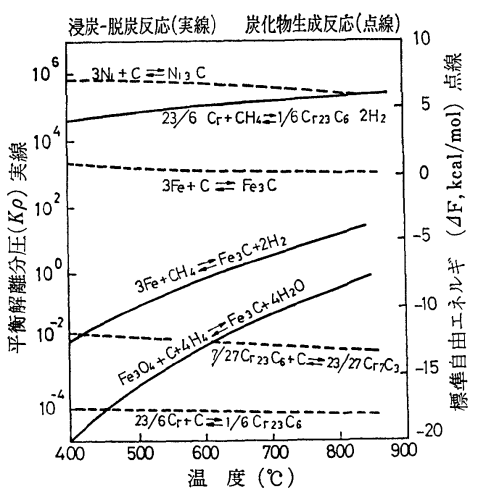

図 6・4 浸炭-脱炭反応, 炭化物生成反応の熱力学 的平衡図

浸炭現象が過度に発生し腐食として問題となる場合 の原因として，(1)浸炭による耐熱，耐食性の低下，(2) 浸炭一脱炭または浸炭一酸化などの交番作用による腐食 の促進, (3)浸炭に上る密度, 硬さ, 伸びなどの物理的 性質の変化により, 環境の温度変化に伴う浸炭部の結 晶の崩れやき裂の発生などが挙げられる.一般にこの 種の環境には $\mathrm{Cr}-\mathrm{Ni}$ 鋼が用いられているが, 表面か ら浸入したCは耐熱, 耐食性を営む $\mathrm{Cr}$ と選択的に反 応し， $\mathrm{M}_{23} \mathrm{C}_{6}$ あるいは $\mathrm{M}_{7} \mathrm{C}_{3}$ 型で代表される炭化物を 形成する. $\mathrm{M}_{23} \mathrm{C}_{6}$ 型炭化物中の $\mathrm{Cr}$ 濃度は析出温度に よって異るが, 60〜75\%の範囲にあり, 鋼中の $\mathrm{Cr}$ 濃 度に比べはるかに高くなっている. いま $\mathrm{M}_{23} \mathrm{C}_{6}$ 中の Mがすべて Cr であるとすると，C 1\%に対し約17\% の $\mathrm{Cr}$ が消費されたこととなるので, 金属内部からの $\mathrm{Cr}$ の供給が充分でない場合は, 析出した炭化物周辺 は甚だしい Cr 欠乏領域を形成することとなり，耐熱， 耐食性は著しく低下することとなる，実際に浸炭腐食 を受けた炭素鋼は全面腐食, ステンレス鋼は Cr 欠之 部が腐食されたと思われる点食を示すことが多い。

\section{$6 \cdot 5$ 水素 侵 害}

アンモニア, メタノール拈よび尿素合成, 石油の改 質, 脱硫などの石油化学プラントでは高温高圧の $\mathrm{H}_{2}$ を使用するので, 構成材料がHによって化学的侵食を 受けぜい化，破損する障害がある。一般にHによるぜ い化現象には，水素ぜい化とよばれる常温における鋼 材の伸び括よび絞りを著しく低下させたり，あるいは 遅れ破壊 (Delayed failure) を誘発するものと, 鋼中 に侵入したHが高温下で鋼中の不安定な炭化物と反応 して炭化水素を生成し，そのガス圧によって粒界き裂 を発生したり，脱炭を促進させて鋼材の強度とじん性 を甚だしく低下さす水素侵害現象に分汀られる. 水素 ぜい化は可逆的現象で, 鋼中の水素を加熱などによっ て放出させるとぜい性は回復するが，水素侵害は非可 逆的であり問題が頗る大きい。このような現象はHの 化学的作用に起因するもので, 原子半径の小さい $\mathrm{H}$ 原
子は容易に鋼中に拡散浸透し，高温状態で鋼中に含ま れている各種の元素扣よび化合物と反応するためであ る.C拈よびC化合物と反応する場合は脱炭反応 (Decarburization), S拈よびS化合物との反応は脱 硫 (Desuphurization)，P拉よび $\mathrm{P}$ 化合物との反応は 脱燐 (Dephosphorization), NおよびN化合物との反 応は脱窒 (Denitriding), 酸化物との反応を脱酸 (Deoxidation) 現象として知られて抢り, 種々な障害を与 えることが知られている.

水素侵害の機構は, 鋼中に侵入した $\mathrm{H}$ と鋼中の固溶 炭素拉よび炭化物が反応して $\mathrm{CH}_{4}$ を生成するために 起るが，脱炭や粒界割れ現象が発生するかどうかは， 粒界部への $\mathrm{H}$ 㐨よび Cの供給速度, 粒界部の $\mathrm{CH}_{4}$ 反 応速度と平衡 $\mathrm{CH}_{4}$ 圧力に支配される.

$$
[\mathrm{C}]+2 \mathrm{H}_{2} \rightleftharpoons \mathrm{CH}_{4}
$$

$$
\log \left(\mathrm{P}_{\mathrm{CH}_{4}} / \mathrm{P}^{2} \mathrm{H}_{2}\right)=9980 / \mathrm{T}-9.20+\log [\mathrm{C}] \quad \text { (27) }
$$

ここに, [C] : 粒界部の炭素濃度 $(\%), \mathrm{P}_{\mathrm{H}_{2}}$ は粒 界の空げき内の水素圧力 (atm), $\mathrm{P}_{\mathrm{CH}_{4}}$ は同メタンガ 不圧力平衡値 $(\mathrm{atm}), T$ は絶対温度 $\left({ }^{\circ} \mathrm{K}\right)$ であり, 平 衡 $\mathrm{CH}_{4}$ 圧力は空げき内の水素圧力と温度の関数であ るとともに，粒界周辺の鋼中の炭素濃度の関数である.

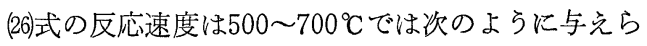
れている.

$$
v=K^{P} \mathrm{CH}_{4} / \mathrm{p}_{\mathrm{H}_{2}}{ }^{1 / 2}-K^{\prime}[C] P_{\mathrm{H}_{2}}{ }^{3 / 2}
$$

ここに $K^{\prime}$ は脱炭速度定数である.

炭化物とHとの反応は炭化物の種類によって異り, 一般飞炭化物形成元素である $\mathrm{Mn}, \mathrm{Cr}, \mathrm{W}, \mathrm{Mo}, \mathrm{Nb}$, $\mathrm{Zr}, \mathrm{V}, \mathrm{Ti}$ は安定度の高い炭化物を形成するため, 耐 水素限界温度が高くなり， $\mathrm{Si}, \mathrm{Ni}, \mathrm{Cu}$ などの非炭化 物形成元素では効果は認められていない, 表 $6 ・ \mathbb{N}$ は 炭化物と $\mathrm{H}$ と反応の $\Delta F$ を示したもので, $\mathrm{Fe}_{3} \mathrm{C}$ の 一部でも Mo, Cr, Ti などの炭化物で置換されると 上り耐水素性が向上することとなる. 耐水素侵食鋼に は, Mo, Cr, Ti などが添加されているのは, 以上の ような理由によるものである。

鋼材を高温高压水素中に暴露してもすぐに水素侵食

\begin{tabular}{|c|c|c|c|}
\hline 反 & 応 & $\left|\begin{array}{c}\text { 適用愠度範囲 } \\
\left({ }^{\circ} \mathrm{K}\right)\end{array}\right|$ & $\begin{array}{c}\text { 標隼自由エネルギ } \\
(\Delta F \mathrm{Cal} / \mathrm{mol})\end{array}$ \\
\hline $\mathrm{Fe}_{3} \mathrm{C}+2 \mathrm{H}_{2}$ & $\rightleftarrows 3 \mathrm{Fe}+\mathrm{CH}_{4}$ & $463 \sim 1115$ & $-27930+32.08 \mathrm{~T}$ \\
\hline $\mathrm{MoC}+2 \mathrm{H}_{2}$ & $\rightleftarrows 2 \mathrm{Mo}+\mathrm{CH}_{4}$ & $500 \sim 1273$ & $-14850+26.16 \mathrm{~T}$ \\
\hline $7 / 5 \mathrm{Cr}_{3} \mathrm{C}_{2}+2 \mathrm{H}_{2}$ & $\rightleftarrows 3 / 5 \mathrm{Cr}_{7} \mathrm{C}_{3}+\mathrm{CH}_{4}$ & $500 \sim 1673$ & $-18350+26.36 \mathrm{~T}$ \\
\hline $\begin{aligned} 23 / 27 \mathrm{Cr}_{7} \mathrm{C}_{3} & \\
& +2 \mathrm{H}_{2}\end{aligned}$ & $\rightleftarrows \begin{array}{r}7 / 27 \mathrm{Cr}_{23} \mathrm{C}_{6} \\
+\mathrm{CH}_{4}\end{array}$ & $500 \sim 1673$ & $-11500+29.01 \mathrm{~T}$ \\
\hline $1 / 6 \mathrm{Cr}_{23} \mathrm{C}_{6}+2 \mathrm{H}_{2}$ & $\rightleftarrows 23 / 6 \mathrm{Cr}+\mathrm{CH}_{4}$ & $500 \sim 1673$ & $-5170+27.07 \mathrm{~T}$ \\
\hline $\mathrm{VC}+2 \mathrm{H}_{2}$ & $\rightleftarrows \mathrm{V}+\mathrm{CH}_{4}$ & $500 \sim 2000$ & $-9050+24.56 \mathrm{~T}$ \\
\hline $\mathrm{T} 1 \mathrm{C}+2 \mathrm{H}_{2}$ & $\rightleftarrows \mathrm{Ti}+\mathrm{CH}_{4}$ & $500 \sim 1160$ & $22200+23.75 \mathrm{~T}$ \\
\hline $\mathrm{WC}+2 \mathrm{H}_{2}$ & $\rightleftarrows \mathrm{W}+\mathrm{CH}_{4}$ & $500 \sim 2000$ & $-12450+25.74 \mathrm{~T}$ \\
\hline
\end{tabular}
を受けず，ある期間経過した後に割れを発生する。こ

表 $6 \cdot \mathrm{N}$ 炭化物と水素との反応の標準自由エネルギ 
の期間を潜伏期間とよび，(26)式の反応によって生成し た $\mathrm{CH}_{4}$ の圧力が高くなり, 粒界割れが発生するまで の時間に当る. 潜伏時間の温度依存性については, Arrhenius の式が成立することが知られ, また潜伏過 程に打ける反応速度は水素圧の 3 乗に比例すると云わ れている.

水素侵害の実用上の潜伏期間を示すものに Nelson 線図が有名である．実プラントで発生した水素侵害の 事例を収集して作図したものであるが，事例の堌加お よびその分布などによって若干の変遷を重ねるととも に, (1)炭素鋼について溶接部, 熱間加工部の安全域を 母材より低水素側へ移す, (2)微量成分の影響の明示, (3)炭素鋼および $0.5 \mathrm{Mo}$ 鋼について時間寿命を示すな どの改善が行われている.

\section{$6 \cdot 6$ 窒 化 腐 食}

窒化腐食はアンモニア合成塔内の高温高圧下におけ る $\mathrm{NH}_{3}$ とその解離カスの共存環境で発生するのが有 名である.この環境における空化反応は， $2 \mathrm{NH}_{3} \rightleftarrows 2 \mathrm{~N}$ $+3 \mathrm{H}_{2}$ によって発生した原子状の窒素（N) が鋼中に 拡散浸透することによって起るが，この反応から明ら かなように，Hによる障害も同時に発生することが多 い. 鋼中に侵入したN゚は, 安定な酸化物を形成しやす

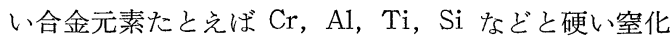
物を形成するのみならず, $\mathrm{Cr}$ 炭化物 $\left(\mathrm{Cr}_{7} \mathrm{C}_{3}\right)$ とも反 応することが知られているので， ํㅗとをもに侵入した $\mathrm{H}$ がこの不安定な炭化物と反応して $\mathrm{CH}_{4}$ の発生を促 す結果, 水素侵害が促進されることとなる. したがっ て, 窒化腐食と水素侵害が同時に発生するよらな環境 では, ํㅠによって Cr の消費が促されるので, Nelson 線図ど括りの材料選択では水素侵害を受けることがあ る.

鋼が窒化されるとじん性を失い, 熱膨張率の異る化 合物が形成されるため, 温度の変化に伴ってひずみを 生じ, これに耐兄られなくなった窒化層はき裂を起し たり脱落する. 欠陥部では再び窒化反応が激しくなる ので, このような現象が繰返し行われることによって 腐食が進行する. 現象論的には酸化腐食における酸化 膜や，浸炭腐食に抢ける浸炭層の破壊による腐食促進 過程と同様である.

窒化腐食の速度は鋼中に抢ける $\mathrm{N}$ の拡散速度に支配 されるが, 㧫の拡散係数 (D) は $\mathrm{Al}, \mathrm{Si}, \mathrm{Cr}$ などの 添加元素に比べかなり大きい（たとえば $900{ }^{\circ} \mathrm{Cにおけ}$ る $D \times 10^{-5} \mathrm{~cm}^{2} /$ day は $\left.\mathrm{N}: 520, \mathrm{Al}: 33\right)$. また $\alpha-\mathrm{Fe}$ 中の Dは $r-\mathrm{Fe}$ 中より $950^{\circ} \mathrm{C}$ に打いて約50倍も大きい ので，鋼種によって腐食速度の変化は大さい。一般に， $\mathrm{Ni}$ 含有量の多い鋼種ほど 窒化層の生成が少くなって いる.

\section{6・7 あ と がき}

実プラントでしばしば遭遇する主要な高温腐食現象 の概要を説明した. 高温腐食の個々の現象括よび機構 などはかなり明らかにされているとはい光，水溶液腐 食に比べると不明な点が少くない，とくに実際の腐食 障害は, 必ずしも単独現象ではないので, 障害を律速 する原因の究明がより重要になってくるまたプラン トでは原因の究明のみならず，実用的な対策を確立す ることが急務であるが，防食の実際的な方法，操作を 研究開発する背景には, 腐食反応扣よびその機構を理 解することが前提条件であると思われるので，この方 面の一助となれば幸いである。

\section{参 考 文 献}

1) Wagner, C., Z. Phys. Chem., 21, 25 (1933).

2) Mott, A.F., Trans. Faraday Soc., 35, 1175 (1936) ; 36, 472 (1940).

3）吉沢四郎，日本材料学会第 7 回腐食防食に関する講習会 テキスト (1968).

4）西田恵三，防食技術，23， 507 (1974).

5）新居和嘉, 防食技術，26，389 (1977).

6) Cunningham, G. M., and A. des Brasunas, Corrosion, 12, 389t (1956).

7) Von. S. Pollmann, V. G. B, 94, 7 (1965).

8) Fitzer, E., J. Schwab, Corrosion, 12, 459t (1956).

9) Simons, E. L., and G. V. Browing, Corrosion, 11, $505 t$ (1955).

10) Danek, G. J., Naval Eng., 77, 859 (1965).

11) Nelson, W., and C. Cain, Trans. ASME, 59-A-89 (1960).

12）成田敏夫，西田恵三，第17回腐食防食討論会講演集, B-2-9; B-2-10 (1970).

13）大久保勝夫，日本材料学会腐食防食部門委員会資料， 13, 73, 23 (1975).

14) Lefrancois, P. A., and W.B. Hoyt, Corrosion, 19, $360 t$ (1963).

15）西野知良, 佐藤綱一，ケミカル・エンジニアリング, p. 838 (1966).

16）矢島悦次郎，日本金属学会刊行，鋼の浸炭拉よび窒化

17）笛木和雄, 日本金属学会報，14，125（1975）.

18）山崎大蔵，新川利和他，三菱重工技報， 13，No.1(1976).

19）石塚 寛, 千葉隆一, 石油学会誌, 11, 838 (1968).

20）西野和良, 賀川直彦, 石油学会誌, 11, 865 (1968).

21）根本 正, 正岡 功, 田野崎和夫, 日立評論日立研究所 創立30周年記念論文集 (1964).

22）木島 茂, 日本材料学会第36回腐食防食部門委員会資料, p. 12 (1968).

23）岡 光, 高圧ガス, 13, 299 (1976).

24）谷口豊吉，山形幸蔵，石坂兼雄，高圧ガス協会誌，18, 154 (1954). 